\title{
Determination of the etiological agent of brown ring disease in southwestern Spain
}

\author{
D. Castro ${ }^{1}$, J. A. Santamaría ${ }^{2}$, A. Luque ${ }^{1}$, E. Martínez-Manzanares ${ }^{1}$, J. J. Borrego ${ }^{1, *}$ \\ ${ }^{1}$ Departamento de Microbiología, and ${ }^{2}$ Departamento de Biología Celular y Genética, \\ Facultad de Ciencias, Universidad de Malaga, E-29071 Málaga, Spain
}

\begin{abstract}
Since 1989 the presence of organic brown deposits on the inner surface of the shells of cultured manila clams Tapes philippinarum associated with episodes of high mortality has been recorded on the southern Atlantic coast of Spain. The gross signs observed in diseased clams were identical to those previously described in France as brown ring disease (BRD), caused by strains of Vibrio tapetis sp. nov. This bacterial pathogen has been isolated in several French clam production areas, and recently in BRD-affected clams cultured in Galicia (NW Spain) and Portugal, using bacteriological procedures. However, this methodology has failed to detect the pathogen in microbiological studies carried out in southwestern Spain. In the present study, an immunodetection test, based on the indirect immunofluorescence (llF) technique, was developed, using polyclonal antisera to $V$. tapetis whole cells and against outer membrane (OM). This method provided evidence for the presence of the bacterium in all the BRD-affected clams analysed. $V$. tapetis was also detected by the same method in healthy (i.e. asymptomatic) clams, which indicates its opportunistic character.
\end{abstract}

KEY WORDS: Brown ring disease · Vibrio tapetis - Immunodetection - Microbiological analyses

\section{INTRODUCTION}

During summer 1987, mass mortalities of cultured clams were recorded on different clam beds of Brouenou (Finisterre, France) (Flassch 1987). The moribund clams appeared on the surface of the sediment, and most of them exhibited an organic brown deposit on the inner surface of the shell, typically located between the pallial line and the shell margin. Due to the gross signs, this syndrome was called 'brown ring disease' (BRD) (Flassch 1989, Paillard et al. 1989). Early studies carried out in France demonstrated the etiology and transmissibility of the disease (Paillard et al. 1989, Paillard \& Maes 1990).

Conchiolinacious deposits in some bivalve species, similar to those of brown ring, have been associated with a reaction of the mantle to acute irritation caused by several metazoan parasites (mainly trematoda metacercariae) located in the extrapallial cavity (Johannssen 1973, Bartoli 1976, Lauckner 1983). Since no para-

\footnotetext{
- Addressee for correspondence.
}

E-mail: jjborrego@ccuma.uma.es sites were found during histological examinations of BRD (Castro 1994, Paillard et al. 1994), investigations were focused on the search for bacteria as the etiological agent of this new disease.

Maes et al. (1993) and Castro (1994) demonstrated that strains closely related to Vibrio splendidus (formerly named Vibrio P1) are able to provoke the disease signs, by experimental inoculation of healthy clams (Tapes philippinarum and $T$. decussatus). Recently, we demonstrated that all strains of this pathogen constitute a homogeneous group on the basis of their antigenic, phenotypic and genotypic characteristics (Castro et al. 1996), and they were included in a new species, named Vibrio tapetis (Borrego et al. 1996).

Epizootic outbreaks of high mortality associated with the presence of the typical symptomatology of BRD in cultured manila clams have been recorded along the southern Atlantic coast of Spain since 1989 (Castro et al. 1992, Castro et al. 1993a, Muñoz et al. 1993). The present study was carried out to verify whether this syndrome is produced by the same etiological agent as that described in France. 


\section{MATERIAL AND METHODS}

Microbiological analyses. Samples of diseased and healthy (i.e. without signs of BRD) manila clams (50 to 100 specimens) were collected from different clam beds in the Bay of Cadiz and at Huelva (Andalusia, SW Spain). Clams were analysed for the presence of Vibrio spp. and total aerobic bacteria following the methodology described previously (Castro et al. 1990a).

In addition, analysis using individual clams were carried out following the scheme shown in Fig. 1. All strains were identified using 31 standard morphological, physiological and biochemical tests, following the procedures specified by Cowan (1974), Smibert \& Krieg (1981) and West \& Colwell (1984). All biochemical tests were performed using media supplemented with $\mathrm{NaCl}$ at a final concentration of $2 \%$, except tests of growth in $0,1.5,6,8$, and $10 \% \mathrm{NaCl}$. The incubation temperature was $22^{\circ} \mathrm{C}$, unless otherwise stated.

In order to establish phenotypic groups, a numerical analysis was carried out. Clustering was achieved by using the simple matching similarity coefficient (SSM) (Sneath 1972) and the unweighted pair group method with arithmetic averages (UPGMA) (Sneath \& Sokal

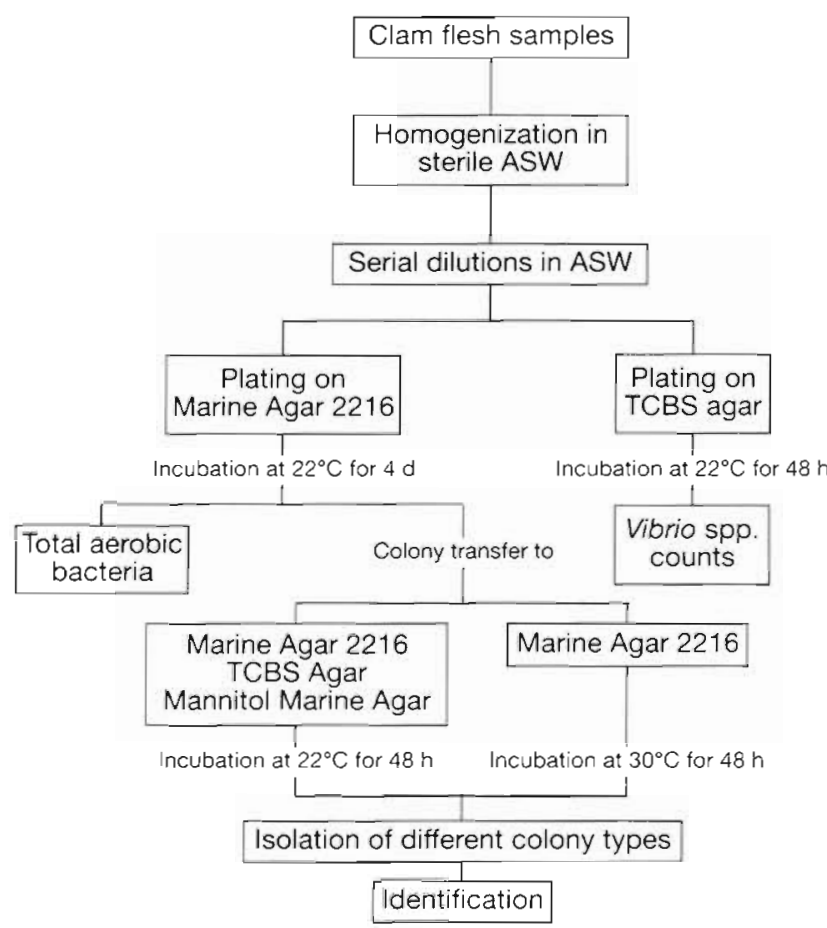

Fig. 1 Microbiological procedure used in this study. ASW: artificial seawater; TCBS: thiosulphate-citrate-bile-sucrose; Mannitol Marine Agar: Marine Agar 2216 supplemented with $1 \%$ mannitol and $0.003 \%$ bromothymol blue
1973). The analyses were performed with the NTSYSpc package (version 1.70) (Rohlf 1992). The taxonomic position of the bacterial isolates was determined according to the criteria of Baumann et al. (1984), Bryant et al. (1986) and West et al. (1986).

Experimental infections. Manila clams were experimentally infected following the methodology described by Paillard \& Maes (1990). Briefly, a volume of $0.1 \mathrm{ml}$ of bacterial suspension [about $10^{8}$ colony forming units (cfu) $\mathrm{ml}^{-1}$ in sterile ASW] was inoculated into the pallial cavity of each clam (12 to $18 \mathrm{~mm}$ in length), avoiding damage to the tissues. As a control, another group of clams was exclusively inoculated with sterile ASW. The clams (50 to 60 per experimental group) were maintained in aquaria with $20 \mathrm{l}$ of $5 \mu \mathrm{m}$ filtered seawater at $19 \pm 1^{\circ} \mathrm{C}$. Thirty days after bacterial inoculation, the specimens were sacrificed, and the presence of signs of the disease was recorded by examination under a stereomicroscope.

The infections were carried out using 22 strains of Vibrio spp. isolated from diseased clams cultured in Andalusia, and belonging to each of the Vibrio groups detected. Similar experiments were also performed using several strains of $V$. tapetis

Immunological methods. In the present study, $2 \mathrm{im}$ munodetection methods, based on the techniques of immunoenzymatic assay (dot-blot) and indirect immunofluorescence (Castro et al. 1995), were evaluated for the detection of Vibrio tapetis from clam pallial cavity fluid.

Two polyvalent antisera were used, one against Vibrio tapetis strain B1090 (CECT 4600) formalin-fixed whole cells (anti-B1090), and the other against outer membranes of the same strain (anti-OM) isolated following the method described by Castro et al. (1996). The specificity of both antisera was analysed using different strains of Vibrio spp. and other Gram-negative bacteria (Table 1).

Indirect immunofluorescence (IIF) assays were carried out on heat-fixed smears $(20 \mu l$ of both bacterial suspensions or pallial cavity fluid), using the anti-B1090 serum (1:2500), and FITC-labelled antiIgG (Sigma Chemical Co., St Louis, MO, USA) (Castro et al. 1995).

Dot-blots were performed as previously described (Castro et al. 1995), using the anti-OM serum (1.40 000). Immobilon-P sheets (Millipore Corp., Belford, MA, USA) were seeded with 100 to $500 \mu \mathrm{l}$ of formalin-fixed samples (bacterial suspensions or intervalvar water) by using a microfiltration apparatus (MilliBlot-D, Millipore). The filters were immunostained using a peroxidase-antiperoxidase complex (PAP, Serva) and 4-chloro-1-naphthol (Sigma) as substrate. 


\section{RESULTS}

\section{Microbiological analyses}

The results obtained in the quantitative analyses of clam flesh are given in Table 2. No significant differences in the bacterial content between healthy and diseased clams were obtained, with arithmetic mean values for healthy and diseased clams of $3.2 \times 10^{5}$ and $3.4 \times 10^{5} \mathrm{cfu} \mathrm{g}^{-1}$ for total aerobic bacteria, and between $8.1 \times 10^{4}$ and $5.3 \times 10^{4} \mathrm{MPN}^{-1}$ for Vibrio spp. When individual specimens were analysed, a high variability in the level of the microbial parameters was detected, although no statistically significant differences were recorded among samples (Table 3).

A total of 173 strains (84 isolated from healthy clams and 89 from brown ring diseased clams) were characterized. All the isolates were considered presumptive Vibrio spp. based on the following traits: motile Gram-negative rods, oxidase-positive, glucose fermentative and sensitivity to the vibriostatic agent $0 / 129(150 \mu \mathrm{g})$. On the basis of the biochemical and physiological characteristics examined, 28 phenotypic patterns were detected. The clustering analysis (Fig. 2) established 9 phenotypic groups; their characteristics are listed in Table 4

Among the 173 strains characterized in the present study, $97.7 \%$ resemble some of the phenons established by Bryant et al. (1986) and West et al. (1986), although several isolates showed differential traits with regard to the phenotypical patterns reported by these authors. The strains included in group 1 presented characteristics that resemble other strains belonging to Vibrio splendidus I, according to the scheme established by West et al. (1986). However, several isolates already included in this group could also be identified as $V$. pelagius (phenon 16), and, in addition, 17 isolates (arginine dihydrolasepositives) showed a pattern that corresponds with the phenon 11 ( $V$. tubiashii) reported by Bryant et al. (1986). Groups 2 to 6 contained strains that resemble those included in phenons 47 and 19 by Bryant et al. (1986) and West et al. (1986), respectively, and classified as $V$. splendidus, although some of the strains (in groups 4 and 6) did not produce acid from mannose and strains included in group 2 were indole-negative, both characteristics being presented by members of $V$. splen- didus. The strains belonging to group 7 correspond with the phenon 29 (Vibrio sp.) proposed by Bryant et al. (1986), and group 9 showed characteristics that resemble the phenon 23 , classified as $V$. harveyi. Finally, the phenotypic pattern showed by strains included in group 8 did not match with any of the Vibrio phenons established by these authors.

Table 1 Microorganisms used in the immunological specificity tests ATCC: American Type Culture Collection; CECT: Spansh Type Culture Collection. TYpe stram

\begin{tabular}{|c|c|c|}
\hline Microorganism & No. of strains & Origin \\
\hline \multirow[t]{2}{*}{ Vibrio alginolyticus } & c & CECT $521^{\top}$ \\
\hline & 1 & CECT 586 \\
\hline \multirow[t]{2}{*}{$V$ anguillarum } & 1 & R82; Serogroup O1 \\
\hline & $\begin{array}{l}1 \\
1\end{array}$ & $\begin{array}{l}\text { ATCC 19264; Serogroup O2 } \\
6062 \text { A }_{\text {; Serogroup O }}{ }^{\circ}\end{array}$ \\
\hline V. campbellii & 1 & CECT $523^{\mathrm{T}}$ \\
\hline$V$ fischeri & 1 & CECT $524_{-}^{\top}$ \\
\hline \multirow{2}{*}{ V. harveyi } & 1 & CECT $525^{\mathrm{T}}$ \\
\hline & 14 & lsolated from diseased clams \\
\hline$V$. natriegens & 1 & CECT $526^{\mathrm{T}}$ \\
\hline$V \cdot$ nereis & 1 & CECT $595^{\mathrm{T}}$ \\
\hline$V$ parahaemolyticus & 1 & CECT 588 \\
\hline$\checkmark$ pelagius & 1 & ATCC $25916^{\top}$ \\
\hline \multirow[t]{3}{*}{$V$ splendidus } & 1 & CECT $528^{\top}$ \\
\hline & 1 & ATCC 25914 \\
\hline & 35 & Isolated from diseased clams \\
\hline \multirow{2}{*}{ V. tubiashii } & 1 & CECT $631^{\top}$ \\
\hline & 5 & Isolated from diseased clams \\
\hline V. vulnificus & 1 & CECT $529^{\top}$ \\
\hline Vibrio sp. & 3 & Isolated from diseased clams \\
\hline V.tapetis & 25 & Isolated from diseased clams ${ }^{b}$ \\
\hline Aeromonas hydrophila & 3 & Isolated from healthy clams \\
\hline Plesiomonas shigelloides & 3 & Isolated from healthy clams \\
\hline P. fluorescens & 1 & Isolated from healthy clams \\
\hline P. fluorescens & 1 & CECT 378 \\
\hline P. aeruginosa & 1 & CECT 110 \\
\hline \multirow[t]{2}{*}{ Escherichia coli } & 1 & ATCC 13706 \\
\hline & 1 & ATCC 11775 \\
\hline \multicolumn{3}{|c|}{$\begin{array}{l}\text { "Kindly supplied by Dr A. E. Toranzo, University of Santiago, Spain } \\
\text { 'Strains isolated from brown ring diseased Tapes philippinarum } \\
\text { cultured in Finisterre. France (Castro et al. 1993b). (Six of these } \\
\text { strains were supplied by Dr P. Maes, University of Bretagne Occi- } \\
\text { dentale. France) }\end{array}$} \\
\hline
\end{tabular}

Table 2. Tapes philippinarum. Quantitative microbiological analyses of samples of healthy and brown ring affected clams. cfu: colony forming units; MPN: most probable number; nd: not done

\begin{tabular}{|c|c|c|c|c|}
\hline \multirow[t]{2}{*}{ Sample } & \multicolumn{2}{|c|}{ Total aerobic bacteria $\left(\mathrm{cfu} \mathrm{g}^{-1}\right)$} & \multicolumn{2}{|c|}{ Vibrio spp. (MPN g-1) } \\
\hline & Healthy & Diseased & Healthy & Diseased \\
\hline 1 & $8.3 \times 10^{4}$ & $1.2 \times 10^{4}$ & $1.1 \times 10^{3}$ & $9.2 \times 10^{2}$ \\
\hline 2 & $18 \times 10^{4}$ & $3.3 \times 10^{4}$ & $1.1 \times 10^{3}$ & $3.0 \times 10^{2}$ \\
\hline 3 & $5.0 \times 10^{4}$ & $3.6 \times 10^{5}$ & $2.4 \times 10^{3}$ & $7.2 \times 10^{3}$ \\
\hline 4 & $3.7 \times 10^{4}$ & $2.0 \times 10^{5}$ & $2.4 \times 10^{3}$ & $4.8 \times 10^{3}$ \\
\hline 5 & $34 \times 10^{5}$ & $18 \times 10^{5}$ & $2.4 \times 10^{4}$ & $23 \times 10^{4}$ \\
\hline 6 & $1.7 \times 10^{4}$ & $1.2 \times 10^{5}$ & $7.2 \times 10^{2}$ & $4.8 \times 10^{3}$ \\
\hline 7 & nd & nd & $2.4 \times 10^{3}$ & $4.8 \times 10^{3}$ \\
\hline 8 & $1.4 \times 10^{5}$ & $1.9 \times 10^{5}$ & $24 \times 10^{4}$ & $6.3 \times 10^{4}$ \\
\hline 9 & $8.0 \times 10^{5}$ & $8.3 \times 10^{5}$ & $4.6 \times 10^{5}$ & $2.4 \times 10^{5}$ \\
\hline 10 & $6.3 \times 10^{5}$ & $6.3 \times 10^{5}$ & $2.3 \times 10^{4}$ & $2.2 \times 10^{4}$ \\
\hline 11 & $9.0 \times 10^{5}$ & $9.3 \times 10^{5}$ & $4.6 \times 10^{5}$ & nd \\
\hline 12 & $6.0 \times 10^{5}$ & $6.0 \times 10^{5}$ & $1.3 \times 10^{4}$ & $1.2 \times 10^{4}$ \\
\hline 13 & $3.7 \times 10^{-3}$ & $1.9 \times 10^{5}$ & $2.4 \times 10^{4}$ & $2.2 \times 10^{4}$ \\
\hline 14 & $1.7 \times 10^{5}$ & $1.2 \times 10^{5}$ & $9.2 \times 10^{4}$ & $2.8 \times 10^{5}$ \\
\hline
\end{tabular}


Table 3. Tapes philippinarum. Microbiological analyses of indıvidual clams. Concentrations expressed as cfu $\mathrm{g}^{-1}$; $\mathrm{SD}$ : standard deviation; ns: not statistically significant

\begin{tabular}{|lcccc|}
\hline Sample & \multicolumn{2}{c}{ Total aerobic bacteria } & & Vibrio spp. \\
& Range & Mean \pm SD & Range & Mean \pm SD \\
\hline Healthy $(\mathrm{n}=15)$ & $1.1 \times 10^{5}-1.1 \times 10^{7}$ & $(1.8 \pm 3.01) \times 10^{6}$ & $2.2 \times 10^{3}-4.2 \times 10^{5}$ & $(9.3 \pm 12.87) \times 10^{4}$ \\
Diseased $(\mathrm{n}=19)$ & $1.2 \times 10^{5}-6.6 \times 10^{6}$ & $(1.8 \pm 1.79) \times 10^{6}$ & $1.0 \times 10^{3}-12 \times 10^{6}$ & $(1.7 \pm 3.05) \times 10^{5}$ \\
Student's $t$ & \multicolumn{2}{c}{0.504} & -0.547 & $0.2966^{\mathrm{ns}}$ \\
Significance $(\mathrm{p})$ & \multicolumn{2}{c}{$0.3110^{\text {ns }}$} & & 0. \\
\hline
\end{tabular}

None of the strains isolated from clams in southwestern Spain showed the same phenotypical profile as Vibrio tapetis, although some of them exhibited close similarities. The main differences between these isolates and $V$. tapetis strains were the ability to grow at $30^{\circ} \mathrm{C}$ and to produce acid from mannitol. On the other hand, none of the groups established was detected exclusively in clams affected by brown ring disease (data not shown); therefore, in the studied area, no relationship between a specific phenotypic profile and the disease could be demonstrated.

\section{Experimental infections}

Experiments with several Vibrio strains isolated from diseased clams cultured in southwestern Spain were performed. In some batches of inoculated clams signs of the disease were recorded at the end of the experi- mental period (30 d after inoculation). However, there were no significant differences $(p<0.01)$ in the percentages of affected individuals between the inoculated and control groups. Thus, the percentages of signs ranged between 0 and $13.2 \%$ in controls compared to 0 to $11.1 \%$ in clams inoculated with several Vibrio strains. However, percentages of BRD signs higher than $90 \%$ were obtained in all the clam groups inoculated with strains of $V$. tapetis.

\section{Immunodetection assays}

Indirect immunofluorescence assays (IIF) were performed by using anti-Vibrio tapetis B1090 serum. No cross-reactions among the strains tested (listed in Table 1) were detected. On the other hand, the dot-blot assay showed the same specificity level, and only $V$. tapetis strains produced a positive reaction with antiOM serum, test sensitivity being $10^{4} \mathrm{cfu}$.

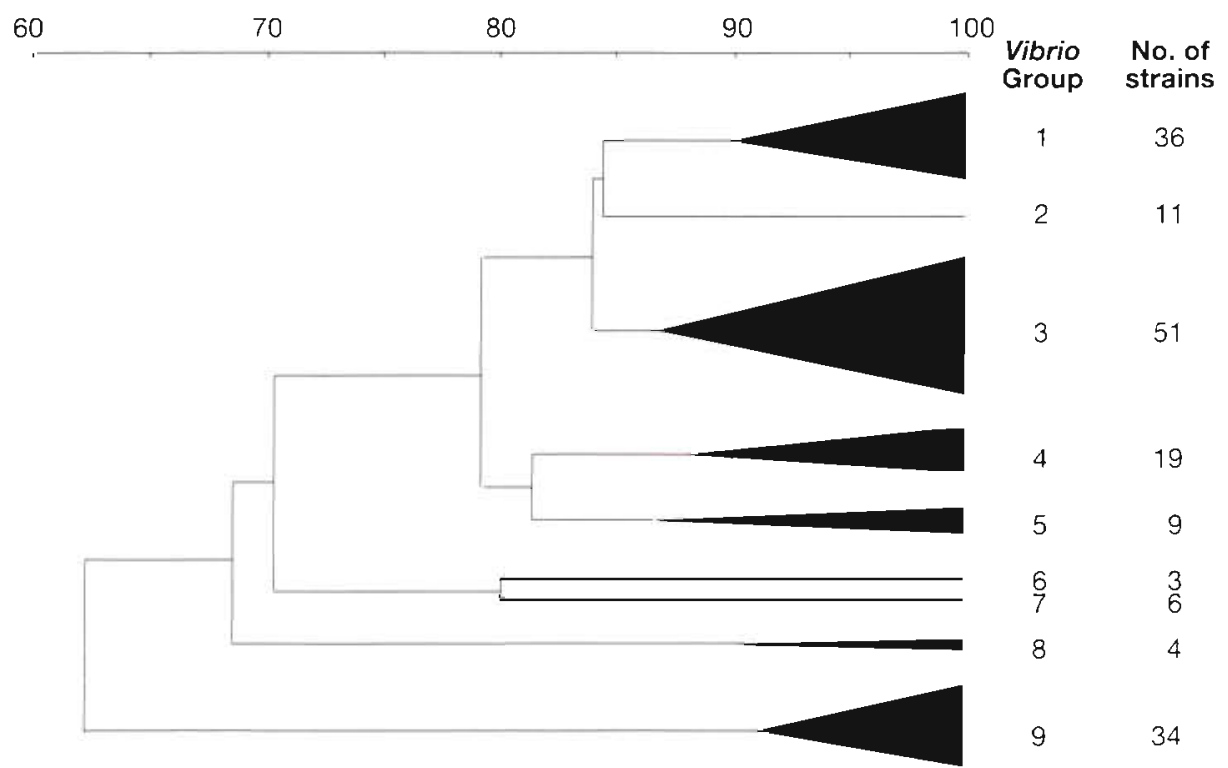

60

$$
70
$$$$
80
$$$$
90
$$

Fig. 2. Condensed dendogram showing the relationship between Vibrio groups defined at $86 \%$ similarity level in a SSM/UPGMA analysis 
Table 4. Charactenstics of Vibrio strains isolated from clams in southwestern Spain. In parentheses: number of strains in each group; + : positive reaction; -: negative reaction; numbers indicate the percentage of strains showing positive reaction; S: susceptible; R: resistant. The characteristics of Vibrio tapetis type strain (CECT 4600) are included.

\begin{tabular}{|c|c|c|c|c|c|c|c|c|c|c|}
\hline \multirow[t]{2}{*}{ Test } & \multicolumn{9}{|c|}{ Vibrio group } & \multirow[b]{2}{*}{ V.tapetis } \\
\hline & $\begin{array}{c}1 \\
(36)\end{array}$ & $\begin{array}{c}2 \\
(11)\end{array}$ & $\begin{array}{c}3 \\
(51)\end{array}$ & $\begin{array}{c}4 \\
(19)\end{array}$ & $\begin{array}{c}5 \\
19)\end{array}$ & $\begin{array}{c}6 \\
(3)\end{array}$ & $\begin{array}{l}7 \\
(6)\end{array}$ & $\begin{array}{c}8 \\
(4)\end{array}$ & $\begin{array}{c}9 \\
(34)\end{array}$ & \\
\hline \multicolumn{11}{|l|}{ Common characteristics } \\
\hline \multicolumn{11}{|l|}{ Growth in: } \\
\hline $0 \% \mathrm{NaCl}$ & - & - & - & - & - & - & - & - & - & - \\
\hline $1.5 \% \mathrm{NaCl}$ & + & + & + & + & + & + & + & + & + & + \\
\hline $10 \% \mathrm{NaCl}$ & & - & - & - & - & - & - & - & - & - \\
\hline \multicolumn{11}{|l|}{ Growth at: } \\
\hline $22^{\circ} \mathrm{C}$ & + & + & + & + & + & + & + & + & + & + \\
\hline $30^{\circ} \mathrm{C}$ & + & + & + & + & + & + & + & + & + & - \\
\hline Swarming & - & - & - & - & - & - & - & - & - & - \\
\hline Voges-Proskauer & - & - & - & - & - & - & - & - & - & - \\
\hline Lipase & + & + & + & + & + & + & + & + & + & + \\
\hline Gas from glucose & - & - & - & - & - & - & - & - & - & - \\
\hline \multicolumn{11}{|l|}{ Acid from: } \\
\hline Arabinose & - & - & - & - & - & - & - & -. & - & - \\
\hline Lactose & - & - & - & - & - & - & - & - & - & - \\
\hline \multicolumn{11}{|l|}{ Differential characteristics } \\
\hline \multicolumn{11}{|l|}{ Growth in: } \\
\hline $6 \% \mathrm{NaCl}$ & + & + & t & - & - & + & + & - & + & - \\
\hline $8 \% \mathrm{NaCl}$ & - & - & - & - & - & + & + & - & - & \\
\hline \multicolumn{11}{|l|}{ Growth at: } \\
\hline $4^{\circ} \mathrm{C}$ & - & - & + & + & + & + & + & + & - & + \\
\hline $35^{\circ} \mathrm{C}$ & 86.1 & + & - & - & & - & - & - & + & - \\
\hline Arginine dihydrolase & 52.8 & + & 49.0 & 94.7 & - & + & - & - & - & - \\
\hline Lysine decarboxylase & - & - & - & - & - & - & + & + & + & - \\
\hline Ornithine decarboxylase & - & - & - & - & - & - & + & 50 & + & - \\
\hline Indole & + & - & 96.1 & + & + & + & + & - & 94.1 & + \\
\hline Gelatinase & + & + & + & 21.1 & + & + & + & + & + & + \\
\hline Amylase & + & + & 96.1 & + & 88.9 & + & + & + & + & + \\
\hline \multicolumn{11}{|l|}{ Acid from: } \\
\hline Sucrose & 94.4 & t & 52.9 & - & 11.1 & + & + & - & 20.6 & - \\
\hline Mannitol & + & - & 76.5 & - & + & + & + & 50 & 88.2 & - \\
\hline Mannose & + & + & + & 78.9 & + & - & + & + & + & + \\
\hline Ampicillin $(10 \mu \mathrm{g})$ & $\mathrm{s}$ & $\mathrm{R}$ & $\mathrm{S}$ & $\mathrm{s}$ & $\mathrm{S}$ & $\mathrm{R}$ & $\mathrm{R}$ & $\mathrm{R}$ & $\mathrm{R}$ & $\mathrm{S}$ \\
\hline
\end{tabular}

Table 5. Comparison of the immunodiagnostic methods used for the detection of Vibrio tapetis. DB: dot-blot assay; w: weak reaction (number of positive samples); -; negative reaction. IIF: indirect immunofluorescence assay; + : detection of immunofluorescent bacteria

\begin{tabular}{|c|c|c|c|c|}
\hline Sample source & Symptomatology & No. samples & \multicolumn{2}{|c|}{ Immunodetection methoo } \\
\hline $\begin{array}{l}\text { Experimental infection } \\
\left(V \text { tapetis, } 10^{7} \mathrm{cfu} \mathrm{clam}^{-1}\right)\end{array}$ & $\begin{array}{l}\text { Healthy } \\
\text { BR diseased }\end{array}$ & $\begin{array}{l}5 \\
5\end{array}$ & $\begin{array}{l}w(5) \\
w(5)\end{array}$ & $\begin{array}{l}+ \\
+\end{array}$ \\
\hline Bay of Cadiz & $\begin{array}{l}\text { Healthy } \\
\text { BR diseased }\end{array}$ & $\begin{array}{l}5 \\
2\end{array}$ & - & $\begin{array}{l}- \\
+\end{array}$ \\
\hline Huelva & $\begin{array}{l}\text { Healthy } \\
\text { BR diseased }\end{array}$ & $\begin{array}{l}5 \\
5\end{array}$ & $w^{-}(1)$ & $\begin{array}{l}+ \\
+\end{array}$ \\
\hline
\end{tabular}

The IIF technique permitted the detection of immunostained bacteria in all the pallial cavity fluid samples from brown ring diseased clams examined and, in several samples, from healthy specimens (Table 5). Although the number of immunofluorescent bacteria varied among samples, the pathogen number in the pallial cavity fluid from clams cultured on the southern Atlantic coast of Spain was about $10^{3}$ bacteria $\mathrm{ml}^{-1}$.

No clear positive reactions were obtained in the samples analyzed by the dot-blot assay (Table 5). Only weak reactions (even when analysing $500 \mu \mathrm{l}$ of pallial 
cavity fluid) were obtained in samples from clams $30 \mathrm{~d}$ after experimental chalienge with the pathogen, and in one sample of diseased clams collected from Huelva.

\section{DISCUSSION}

In the present study, the microbiota of BR diseased clams cultured in southwestern Spain was compared with that of healthy clams. The results obtained did not demonstrate any differences in the levels of bacterial content between healthy and diseased clams. These results were rather surprising, since in other bivalve diseases of bacterial origin a large increase of the bacterial numbers in the tissues of affected specimens has been observed (Garland et al. 1983, Bolinches et al. 1986, Castro et al. 1990d, Hazañas et al. 1990, Olafsen et al. 1993).

The bacteriological analyses of brown deposits showed that more than $95 \%$ of the isolates belonged to the Vibrio genus, with a high diversity of physiological and biochemical characteristics (Castro et al. 1990b). In addition, strains of $V$. tapetis (formerly Vibrio P1) isolated from France have been demonstrated to be the etiological agent of BRD, because of their ability to produce the typical symptoms after challenge experiments (Paillard \& Maes 1990). Therefore, subsequent studies were focused on characterization of members of this genus isolated from diseased clams in the southwest of Spain. These studies were carried out using the bacteriological procedure specified in Fig 1. This methodology has been successfully used to detect the pathogen both in flesh and palljal cavity fluid of affected clams collected in different clam-production areas in France (Paillard \& Maes 1990, Maes 1992, Castro et al. 1993b).

The results obtained showed the presence of a particular microbiota associated with the disease. However, none of the isolates could be phenotypically typed as Vibrio tapetis. Thus, more than $74 \%$ of the Vibrio strains isolated from manila clams have been identified as members of the $V$. pelagius $/ V$. splendidus group (formerly called $V$. anguillarum-related, or VAR organisms) (Larsen 1983, Fouz et al. 1990, Myhr et al. 1991). Frequently, these VAR vibrios were the only bacteria of the Vibrio genus in the microbiota of these clams, similar to that reported previously by Castro et al. (1993b) studying diseased clams collected in Brouenou (France). In fact, $V$. tapetis was previously included in this group based on its biochemical characteristics (Castro et al. 1992)

Several studies have established that the development of an epizootic disease depends, in part, on environmental conditions, which affect the presence of an adapted microbiota (Olafsen et al. 1981, 1993). In this sense, the main physiological differences detected between the Vibrio strains isolated in southwestern Spain and in France were the salt tolerance and the range of growth temperature (Castro et al. 1993b). In addition, the epizootic studies carried out in Andalusia demonstrated clear differences concerning the seasonal development of the disease compared to that established in France (Castro 1994). These findings suggest that the disease detected in Andalusia was related to the presence of other bacteria, different from $V$. tapetis, which are adapted to the specific environmental conditions of that area.

To test this hypothesis, experimental infections of manila clams with several strains of Vibrio spp. isolated from diseased clams cultured in Andalusia were performed. None of these strains provoked a significant increase in the percentage of symptoms in the inoculated clams compared to control clams. However, more than $90 \%$ of the inoculated clams were affected in infection experiments performed with different strains of $V$. tapetis. The symptoms observed in these specimens were similar, both macroscopically and histologically, to those observed in cultured clams affected by BRD in Andalusia (Castro 1994).

Another aspect to be considered is that Vibrio tapetis has been isolated, using the same bacteriological protocol, from the pallial cavity fluid of brown, ring diseased clams cultured in Galicia (northwestern Spain) and Portugal (Robledo et al. 1994). These findings suggest that the causative agent of BRD could be the same in all the regions where the epizootic outbreaks have been recorded.

Therefore, it will be necessary to understand why the bacteriological procedure fails to detect Vibrio tapetis from cultured clams in Andalusia. An important factor to consider is that in southwestern Spain the level of the pathogen in the tissues of the affected clams is lower than in France and Galicia. For this reason, it was necessary to develop a more sensitive detection method, and to enhance the specificity of $V$. tapetis detection against the interference of other vibrios present.

The immunological techniques applied for the detection of bacterial pathogens are usually more sensitive than the classical bacteriological methods, and, therefore, allow pathogen detection in samples where their isolation on culture media fail (Lee \& Gordon 1987. Bernoth 1991, Sakai \& Kobayashi 1992).

In the present study, 2 immunological methods, based on the techniques of immunoenzymatic assay (dot-bJot) and indirect immunofluorescence (IIF), were used to detect Vibrio tapetis from pallial cavity fluid of clams. Although the serological methods improve the sensitivity of the bacterial detection, these techniques can lack specificity of the antibodies. Cross-reactions 
among related Vibrio species (for example $V$. anguillarum and $V$. ordalii or $V$. alginolyticus and $V$. parahaemolyticus), or even between several Vibrio sp. and other members of the Vibrionaceae family, have been reported (Ito \& Yokota 1987, Svendsen \& larsen 1988, Chen et al. 1992).

In this study, the dot-blot assay using antiserum against outer membranes of the pathogen showed specificity for Vibrio tapetis strains, and no crossreactions were recorded with the other strains tested. In the case of the IIF technique, the serum against whole cells yielded similar results.

The use of the IIF technique demonstrated the presence of Vibrio tapetis in brown ring diseased clams cultured in southwestern Spain. The concentration of the pathogen determined by this method is about $10^{3}$ cells $\mathrm{ml}^{-1}$ of pallial cavity fluid. This low bacterial concentration explains why this pathogen was not isolated by the bacteriological procedure, since the levels of aerobic bacteria in pallial cavity fluid of clams ranged between $2 \times 10^{5}$ and $3 \times 10^{6} \mathrm{cfu} \mathrm{m}^{-1}$ (results not shown). In addition, the IIF technique does not demonstrate the viability of the bacteria present in the samples, and therefore, the pathogen concentration (expressed as culturable cells) could be even lower

The sensitivity of the dot-blot assay was $10^{4} \mathrm{cfu}$, similar to that reported by other authors using monoclonal antibodies against several Vibrio pathogens (Song et al. 1992). This detection limit is not adequately sensitive, as mentioned above, for the detection of the pathogen in clam samples, and thus it can explain the negative results obtained in the samples of pallial cavity fluid.

In the bacteriological analyses carried out in France, the count of Vibrio tapetis ranged between $2.8 \times 10^{4}$ and $3.8 \times 10^{5} \mathrm{cfu} \mathrm{g}^{-1}$ of flesh homogenates, and $5 \times 10^{4}$ and $8.1 \times 10^{5} \mathrm{cfu} \mathrm{m}^{-1}$ of pallial cavity fluid (Castro 1994). Similar results have been reported in the studies carried out in Galicia and Portugal (Robledo et al. 1994). Therefore, in the clams cultured in the southwest of Spain, brown ring disease could be associated with a lower infection degree or with a lower growth of the pathogen in the host tissues. Recently, antibacterial activity against $V$. tapetis has been observed in several other Vibrio strains isolated from brown ring diseased clams collected in Andalusia. This inhibitory activity seems to be related to bacteriocin synthesis by these Vibrio strains.

It has to be considered that the establishment of an infectious disease is a process that involves both microbial pathogenicity and defense mechanisms of the host. Thus, the low concentration of Vibrio tapetis detected in clams cultured in Andalusia could be explained by the different environmental conditions that affect both the pathogenic capabilities of the bac- teria and the host responses, as well as the antagonistic relationship established among the microbiota. Finally, $V$ tapetis has also been detected by the use of the IIF technique in healthy (i.e asymptomatic) clams. Therefore, this immunological method could be a valid tool for prophylactic purposes, because it allows detection of the pathogen in carrier clams.

Acknowledgements. This study was supported by grant no. AQ-3-763 from the Commission of the European Communities (FAR Program), and grant no. 807/35369 from the Dirección General de Pesca (Consejería de Agricultura y Pesca Junta de Andalucia). Critical reading of the manuscript by Dr Alicia E. Toranzo is gratefully appreciated.

\section{LITERATURE CITED}

Bartoli P (1976) Modification de la croissance et du comportement de Venerupis aurea parasité par Gymnophallus fossarum P. Bartoli, 1965 (Trematoda, Digenea). Haliotis 7 : $23-28$

Baumann P, Furniss AL, Lee JV (1984) Genus 1 Vibrio Pacini 1854, 411 $1^{\text {AL }}$ In: Krieg NR, Holt J (eds) Bergey's manual of systematic bacteriology, Vol 1. Williams \& Wilkins Co, Baltimore, p 518-538

Bernoth EM (1991) ldentification of cultured Aeromonas salmonicida by an indirect dot blot immunoassay. J Fish Dis $14: 419-422$

Bolinches J, Toranzo AE, Silva A, Barja JL (1986) Vibriosis as the main causative factor of heavy mortalities in the oyster culture industry in Northwestern Spain. Bull Eur Assoc Fish Pathol 6:1-4

Borrego JJ, Castro D, Luque A, Paillard C, Maes P, García MT, Ventosa A (1996) Vibrio tapetis sp. nov., the causative agent of the brown ring disease affecting cultured clams. Int J Syst Bacteriol 46:480-484

Bryant TN, Lee JV, West PA, Colwell RR (1986) Numerical classification of species of Vibrio and related genera. $\checkmark$ Appl Bacteriol 61:437-467

Castro D (1994) Patologías de origen bacteriano en almejas cultivadas (Tapes decussatus y $T$ philippinarum). PhD thesis, University of Malaga

Castro D, Luque A, Gomez JM, Martínez-Manzanares E, Borrego JJ (1993a) Descripción de epizootías de origen microbiano en el cultivo de la almeja fina (Tapes decussatus) y japonesa ( $T$ philippinarum). EAS Spec Publ 19:51

Castro D, Luque A, Martínez-Manzanares E, Borrego JJ (1993b) Comparación de la flora microbiana prevalente en almejas japonesas (Tapes philippinarum) sanas $y$ afectadas por la enfermedad del anillo marrón. In: Cerviño A, Landin A, de Coo A, Guerra A, Torres M (eds) Actas del IV Congreso Nacional de Acuicultura. Grafinova, Santiago de Compostela, p 621-626

Castro D, Luque A, Santamaría JA, Maes P, MartínezManzanares E, Borrego JJ (1995) Development of immunological techniques for the detection of the potential causative agent of the brown ring disease. Aquaculture 132:97-104

Castro D, Martínez-Manzanares E, Luque A, Fouz B, Morinigo MA, Borrego JJ, Toranzo AE (1992) Characterization of strains related to brown ring disease outbreaks in southwestern Spain. Dis Aquat Org 14:229-236 
Castro D, Morinigo MA, Cornax R, Balebona MC, Borrego JJ (1990a) Detection of potentially pathogenic bacteria in semintensive culture of fine clams (Tapes decussatus) from Southwest Spain. Bull Eur Assoc Fish Pathol 10:50-53

Castro D. Moririgo MA. Cornax R, Martínez-Manzanares E, Borrego JJ (1990b) Microflora associated with outbreaks of 'brown ring' from clams (Tapes semidecussatus) in Southwestern Spain. In: Figueras A, Fisher WS, van Banning $P$ (eds) 4 th Int Colloquium on Pathology in Marine Aquaculture. Instituto Investigaciones Marinas, Vigo, p 86

Castro D, Santamaria JA, Luque A, Martínez-Manzanares $E_{1}$ Borrego JJ (1996) Antigenic characterization of the etiological agent of the brown ring disease affecting manila clams. Syst Appl Microbiol 19:231-239

Chen D, Hanna PJ, Smith A, Moon P, Hammond L (1992) Development of monoclonal antibodies that identify Vibrio species commonly isolated from infections of humans, fish, and shellfish. Appl Environ Microbiol 58:3694-3700

Cowan ST (1974) Cowan and Steel's manual for the identification of medical bacteria, 2nd edn. Cambridge University Press, London

Flassch JP (1987) L'elevage des palourdes en France en 1987. Aqua Revue 15:12-16

Flassch JP (1989) Bilan des travaux sur la maladie des anneaux bruns chez la palourde de l'élevage. Equinoxe $29: 9-11$

Fouz B, Conchas RF, Bolinches J, Romalde JL, Barja JL, Toranzo AE (1990) Relationship among pathogenic Vibrio anguillarum and Vibrio tubiashii with environmental vibrios. In: Perkins FO, Cheng TC (eds) Pathology in marine science. Academic Press, New York, p 77-89

Garland CD, Nash GV, Summer CE, McMeekin TA (1983) Bacterial pathogens of oyster larvae (Crassostrea gigas) in a Tasmanian hatchery. Aust J Mar Freshwat Res 34:483-487

Hazañas M, Carrasco MI, Castro D, García-Casado JL, Cornax R, Martínez-Manzanares E. Borrego JJ (1990) Estudio de la infección experimental de Tapes decussatus por cepas de Vibrio alginolyticus aisladas de brotes epizoóticos. In: Landín A, Cerviño A (eds) Actas del III Congreso Nacional de Acuicultura. Grafinova, Santiago de Compostela, p 903-908

Ito $T$, Yokota $T$ (1987) Different types of monoclonal antibodies to Ogawa-specific and group-specific antigens of Vibrio cholerae O1. J Clin Microbiol 25:2289-2295

Johannssen OH (1973) Deformations of the inner shell surface of Venerupis pullastra (Montagu) (Lamellibranchia) as a result of infection by a trematod metacercaria. Sarsia 52 $117-121$

Larsen JL (1983) Vibrio angullarum: a comparative study of fish pathogenic, environmental, and reference strains. Acta Vet Scand 24:456-476

Lauckner G (1983) Diseases of Mollusca: Bivalvia. In: Kinne O (ed) Diseases of marine animals, Vol II. Biologische Anstalt Helgoland, Hamburg, p 477-961

Lee EGH, Gordon MR (1987) Immunofluorescence screening of Renibacterium salmoninarum in the tissues and eggs of farmed chinook salmon. Aquaculture 65:7-14

Maes P (1992) Pathologie bactérienne chez deux invertébrés marins d'intérét commercial, Ruditapes philippinarum et Paracentrotus lividus. Thèse dr Univ Bretagne Occidentale, Brest
Maes P, Paillard C, le Pennec M, Flassch JP (1993) Specificity level of the brown ring disease. EAS Spec Publ 19:38

Muñoz JL, Sanchez-Lamadrid A, Saavedra M (1993) Incidencia del anillo marrón en cultivos intermareales de la almeja japonesa (Ruditapes philippinarum). EAS Spec Publ 19:72

Myhr E, Larsen JL, Lillehaug $A$, Gudding $R$, Heum $M$, Hastem $T$ (1991) Characterization of Vibrio angullarum and closely related species isolated from farmed fish in Norway. Appl Environ Microbiol 57:2750-2757

Olafsen JA, Christie M, Raa J (1981) Biochemical ecology of psychrotrofic strains of Vibrio anguillarum isolated from outbreaks of vibriosis at low temperature. Syst Appl Microbiol 2:339-348

Olafsen JA, Mikkelsen HV, Giaever HM, Hansen GH (1993) Indigenous bacteria in hemolymph and tissues of marine bivalves at low temperatures. Appl Environ Microbiol 59 $1848-1854$

Paillard C, Maes P (1990) Etiologie de la maladie de l'anneau brun chez Tapes philippinarum: pathogénicité d'un Vibrio sp. CR Acad Sci Paris 310:15-20

Paillard C, Maes P, Oubella R (1994) Brown ring disease in clams. Annu Rev Fish Dis 4:219-240

Paillard C, Percelay L, Le Pennec M, Picard DL (1989) Origine pathogène de l' 'anneau brun' chez Tapes philippinarum (mollusque, bivalve). CR Acad Sci Paris 309:235-24.1

Robledo JFA, Cáceres-Mcrtínez J, Figueras A (1994) The presence of the brown ring disease in clams from Galicia (NW of Spain) and Ave:ro (W of. Portugal). In: Vivares CP (ed) 6th Int Colloquium on Pathology in Marine Aquaculture. BIOCIM, Montpellier, p 29

Rohlf FJ (1992) NTSYS-pc. Numerical taxonomy and multivariate analysis system, Version 1.70. Exeter Software. Applied Biostatistics Inc, New York

Sakai M, Kobayashi M (1992) Detection of Renibacterium salmoninarum, the causative agent of bacterial kidney disease in salmonid fish, from pen-cultured coho salmon. Appl Environ Microbiol 58:1061-1063

Smibert RM, Krieg NR (1981) General characterization. In Gerhardt P, Murray RGE, Costilow RN, Nester EW, Wood WA, Krieg NR, Phillips GB (eds) Manual of methods for general bacteriology. American Society for Microbiology, Washington, DC, p 409-443

Sneath PHA (1972) Computer taxonomy. In: Norris JR, Ribbons DW (eds) Methods in microbiology, Vol $7 \mathrm{~A}$. Academic Press, London, p 29-98

Sneath PHA, Sokal RR (1973) Numerical taxonomy: the principles and practice of numerical classification. WH Freeman \& Co, San Francisco

Song YL, Lee SP, Lin YT, Chen CC (1992) Enzyme immunoassay for shrimp vibriosis. Dis Aquat Org 14:43-50

Svendsen I, Larsen JL (1988) Monoclonal antibodies against surface antigens of Vibrio anguillarum serogroup $\mathrm{O} 2$. Acta Vet Scand 29:363-368

West PA, Brayton PR, Bryant TN, Colwell RR (1986) Numerical taxonomy of vibrios isolated from aquatic environments. Int J Syst Bacteriol 36:531-543

West PA, Colwell RR (1984) ldentification and classification of Vibrionaceae. An overview. In: Colwell RR (ed) Vibrios In the environment. John Wiley \& Sons, New York, p 285-363

Manuscript first received: May 9, 1996 Revised version accepted: February 4, 1997
Responsible Sutject Editor: A. K. Sparks, Seattle Washington, USA 